\title{
A Review of 'Building A Lemonade Stand Is Not Just For Kids Anymore'
}

Co-written by Dulce M. Ramirez-Damon, Florida International University

Concepcion L. Tuma, Florida International University

Reviewed by Kimber L. Houlne, CEO and President, Working Solutions

(๑) ften times, as I travel across the country speaking to people interested in working from home, many ask if there is any one resource to walk them through the steps of getting started. They seem to be overwhelmed in really trying to grasp just where to start the process. The amount of documentation required by the state and federal governments is perceived to be so inundating that they just can't seem to get themselves motivated. Building a Lemonade Stand is Not Just for Kids Anymore written by Dulce M.Ramirez-Damon and Concepcion L. Tuma, is the perfect resource for those trying to tackle the start up process.

The simplicity is the reason I loved this book; it encapsulates the most important operational aspects of what is required to start up a company. Typically one has to read several resources to gain a small amount of start-up "know-how"; however, in Building a Lemonade Stand is Not Just for Kids Anymore, useful information is covered in a concise and easy-to-read fashion. The business checklists at the end of the book are both very handy and very thorough. It was enlightening to see that the Appendix provides not only statistics surrounding business fiscal development; it also narrates a view of statistics surrounding the human side of business.

In the Chapter, "Start with Babysteps," Ramirez-Damon and Tuma present concepts and strategies found in Marketing 101 that may often be forgotten. Business basics, like reminding the reader that the Four Ps of marketing are a critical component to a successful marketing plan, is a welcome refresher.

I also enjoyed reading the nice tidbits of business information incorporated throughout the book, including Chapter 5 where the authors exclaim that "Being the Boss Stinks." The book affirms that cultural diversity has an important role in the success of an organization. The authors even make it a point to note that it is not always necessary to have an advanced degree to excel in the business world. "Bill Gates, founder of Microsoft, the world's largest software company, quit Harvard after his sophomore year."

As the title of the book Building a Lemonade Stand is Not Just for Kids Anymore reflects, selling lemonade can be simple, especially if you are supplied with some helpful advice from someone who has accomplished the task. Ramirez-Damon and Tuma have done just that for their readers, providing invaluable tips and resources that anyone can use to start and run a business.

\section{NOTES}


NOTES 